\title{
Noise Assessment in Intensive Care Units
}

Ivan Senis Cardoso Macedo ${ }^{1}$, Daniela Cunba Mateus ${ }^{2}$, Eduardo De Martin Guedes C Costa ${ }^{3}$, Ana Cristina Lanfranchi Asprino ${ }^{4}$, Edmir Américo Lourenço $^{5}$
Keywords: environmental statistics, noise, intensive care units.

\section{Summary}

I Intensive Care Units are environments with numerous noise sources. In different hospital environments it is recommended to have a sound pressure level between 35 and $45 \mathrm{db}(\mathrm{A})$. Aim: To measure the sound pressure levels in three ICU at a hospital in Jundiaí, State of São Paulo, Brazil. Study Design: Observational. Materials and Methods: we used a Minipa model MSL1532C (USA) sound meter, according to the Brazilian Technical Standards (NBR 10151), in order to measure sound levels in the ICUs at different moments, that is, the morning, afternoon and night at peak times of activity. Results: The values found during the checking of the sound pressure levels were $64.1 \mathrm{~dB}$ (A) in the First ICU, $58.9 \mathrm{~dB}$ (A) in the Coronary Unit and $64 \mathrm{~dB}$ (A) in the second ICU. Conclusion: High sound pressure levels in ICU still mean an important health-related problem for patients in these units. None of the three ICU pad levels above $85 \mathrm{~dB}$, showing that there is no occupational risk for the health care teams in the environments studied.

\footnotetext{
${ }^{1}$ Physician, trained at the Jundiai Medical School - Sao Paulo.

2 th year medical student at the Jundiai Medical School - Sao Paulo.

3 th year medical student at the Jundiai Medical School - Sao Paulo.

${ }^{4} 1$ st year medical resident in Otorhinolaryngology, Jundiai Medical School - Sao Paulo.

${ }^{5}$ Professor in the Department of Otolaryngology, Jundiai Medical School - Sao Paulo. Jundiai Medical School, Santo André - Sao Paulo.

Send correspondence to: Francisco Telles, 250 B. Vila Arens Jundiaí SP 13202-550.
}

Paper submitted to the BJORL-SGP (Publishing Management System - Brazilian Journal of Otorhinolaryngology) on September 16, 2008; and accepted on February 8, 2009. cod. 6040 


\section{INTRODUCTION}

Intensive care units (ICUs) contain many sources of noise, such as aspirators, monitors, mechanical ventilators, computers, printers, air conditioning vents, and others. Elevated sound pressure levels may cause stress, psychological disorders, and sleep disorders. ${ }^{1}$ Psychological effects due to loud noise may cause behavioral disorders and physiological responses to stress. Noise may also alter assessments of sedation. ${ }^{2.3}$ The hypothalamicpituitary-adrenal system is sensitive to a sound pressure level of $65 \mathrm{dBA}$; at this level, high amounts of adrenalin, noradrenalin and corticosteroids are secreted, blood pressure may be elevated, the heart rate may be altered and there may be peripheral vasoconstriction. ${ }^{3}$ A further important issue is synergism between ototoxic drugs and high sound pressure levels, which increase the risk of hearing loss in patients. ${ }^{4-7}$ Comfortable noise levels are underestimated in hospitals; finding solutions to improve environmental quality - as related to the level of noise when designing hospitals has been markedly difficult. The United States Environmental Protection Agency and the Brazilian Technical Standards Association (ABNT) have recommended sound pressure levels ranging from 35 to $45 \mathrm{db}$ (A) in various hospital settings. ${ }^{8.9}$

The aim of this study was to measure sound pressure levels in three intensive care units (ICUs) of a Teaching Hospital in Jundiai, Sao Paulo State, Brazil.

\section{METHODS}

A Minipa model MSL-1532C (USA) model was used to measure sound levels in a first ICU, a second ICU, and a Coronary Care Unit (CCU) located in a hospital in Jundiai, Sao Paulo state, according to ABNT standards (NBR 10151). Data gathering and analysis were done following an evaluation and consent of the ICU directors and approval by the Institutional Review Board (protocol approval number FR-226570). Only the physician in charge in each shift was aware of the strategic placement of the sound level measuring device. Measurements were done during two hours per session (morning, afternoon and evening); the number of staff members in the environment being studied was recounted every 5 minutes. Data were analyzed with descriptive statistics using Microsoft's ${ }^{\circledR}$ Excel 2000 software.

\section{RESULTS}

Measurement sound pressure level values were $64.1 \mathrm{~dB}(\mathrm{~A})$ in the first ICU, 58.9 dB (A) in the CCU and $64 \mathrm{~dB}$ (A) in the second ICU. Table 1 shows minimum and maximum sound pressure levels, the mean number of staff on site, and the number of patients in each ICU.

Table 2 shows sound pressure levels as percentages above recommended values; measured according to the site.

Table 1. Description of parameters analyzed according to each unit.

\begin{tabular}{lccc}
\hline \multirow{2}{*}{ Parameter } & & Site & Second ICU \\
\cline { 2 - 4 } & First ICU & CCU & 64.0 \\
\hline Mean - dB (A) & 64.1 & 58.9 & 55.9 \\
Low - dB (A) & 57.0 & 51.9 & 82.4 \\
High - dB (A) & 80.4 & 73.3 & 3.1 \\
Standard deviation & 3.4 & 2.9 & 14 \\
Mean staff number on site & 13 & 8 & 13 \\
Number of patients & 8 & 7 & 13 \\
\hline
\end{tabular}

CCU: Coronary Care Unit, ICU: Intensive Care Unit.

Table 2. Percentage above recommended sound pressure levels measured in each ICU.

\begin{tabular}{cccc}
\hline \multirow{2}{*}{ Parameter } & & Local & \\
\cline { 2 - 4 } & First ICU & CCU & Second ICU \\
\hline Mean - dB (A) & $42.4 \%$ & $30.8 \%$ & $42.2 \%$ \\
Minimum & $26.7 \%$ & $15.4 \%$ & $24.2 \%$ \\
Maximum & $78.7 \%$ & $62.8 \%$ & $83.1 \%$ \\
\hline
\end{tabular}

CCU: Coronary Care Unit, ICU: Intensive Care Unit. 


\section{DISCUSSION}

All ICUs in this study had mean sound pressure levels at least 30\% over recommended values (ABNT and United States Environmental Protection Agency). ${ }^{8.9}$ at no moment during measurements were these values within normal parameters for such institutions; this is a contributing factor to an increased morbidity in patients. Elevated sound pressure levels in hospital environments is common worldwide, as several studies have reported: a mean 60 to $65 \mathrm{~dB}$ (A) in an Austrian hospital, $55 \mathrm{~dB}$ (A) in the University of Valencia hospital, Spain, and $68 \mathrm{~dB}$ (A) in a hospital ICU in Manitoba, Canada;1 these findings are similar to our results.

Noise generated in ICUs has increased in recent decades due to a substantial increase in the number of devices with acoustic alarms, and background noise by actions and speaking of healthcare professionals. Patients and healthcare staff may be affected alike. ${ }^{3}$ There is a high risk of chronic occupational noise exposure, especially with complex tasks. Excessive and continuous noise exceeding $85 \mathrm{~dB}$ may cause physiological and psychological harm in healthcare teams, such as hypertension, altered heart rates and muscle tone, headaches, hearing loss, mental confusion, low attention span and irritability. ${ }^{3}$ However, we measured no values above $85 \mathrm{~dB}$ in this study, showing that there was no occupational health risk for staff in the environments that were investigated.

The design of devices for intensive care units should take noise reduction into account. Noise should be a concern in procurement, installation and use of such devices, as changes at a later date may increase costs. ${ }^{10}$ Thus, awareness of this issue is important for critical care professionals and manufacturers of medical equipment. The amount of noise generated by each device should be established for efficient noise-reducing measure to be adopted, as noise in a workplace may originate from several sources. ${ }^{1.3}$ Guidelines are important, as evidence suggests their relevance as part of training programs for healthcare professionals when attempting to change work sites. ${ }^{4}$ The main issue in such programs is controlling excessive noise to reduce its effects on human hearing, to decrease stress, and to have positive effects on healing. Information for healthcare team helps trigger behavioral changes. Important measures in routine work are: avoiding loud conversations close to patients, generating specific environments for clinical discussions; controlling bells, alarms, cell phones, pagers, televisions and radios, use of posters in critical areas, defining silence periods for sleep hours, during which sound alarms should be turned down or off if possible, and nursing interventions should be kept to a minimum in clinically stable patients. Other measures include collaboration of supporting staff (e.g.: janitors, laboratory and radiology technicians), and implementing continued education programs for ICU staff. Environmental measures include adjusting the ICU architecture by adding noise-absorbing floors, ceilings, and walls, physical separators between beds in larger units, rubber seals on doors and windows, and noise assessments prior to acquiring equipment. $^{3}$

\section{CONCLUSION}

Sound pressure levels above ABNT and United States Environmental Protection Agency recommended values were found in three intensive care at a hospital in Jundiai, Sao Paulo State, Brazil, emphasizing a major inpatient morbidity issue.

At no time did the three ICUs have sound pressure levels over $85 \mathrm{~dB}$, suggesting no occupational health risk to healthcare professionals at those sites.

\section{REFERENCES}

1. Pereira RP, Toledo RN, Amaral JLG, Guilherme A. Qualificação e quantificação da exposição sonora ambiental em uma unidade de terapia intensiva geral. Rev Bras Otorrinolaringol. 2003;69(6):766-71.

2. Freitas SF, Clímaco RSC. Análise do conforto sonoro em hospitais de Brasília. Disponível em http://www.unb.br/fau/pos_graduacao/ paranoa/analise/hospitais.pdf. Acesso em 10 setembro 2008.

3. Carvalho WB, Pedreira MLG, Aguiar MAL. Nível de ruídos em uma unidade de cuidados intensivos pediátricos. J Pediatr. 2005; 81(6):495-8

4. Cmiel CA, Karr, DM, Gasser DM, Oliphant LM, Neveau AJ. Noise control: a nursing team's approach to sleep promotion: respecting the silence creates a healthier environment for your patients. Am J Nurs. 2004;104:40-8.

5. Ray DE. Function in neurotoxicity: index of effect and also determinant of vulnerability. Acta Otorhinolaryngol Ital. 1998;18(4 Suppl 59):55-8.

6. Gendeh BS. Vancomycin administration in continuing ambulatory peritoneal dialysis: The risk of ototoxicity. Otolaryngol Head Neck Surg. 1998;118:551-8.

7. Minoli I, Moro G. Constraints of intensive care units and follow-up studies in prematures. Acta Otolaryngol Suppl. 1985;421:62-7.

8. Elaborado através da Associação Brasileira de Normas Técnicas. Comitê Brasileiro de Construção Civil. Acústica-Avaliação do ruído em áreas habitadas visando o conforto da comunidade - Procedimento. Norma Técnica. ABNT.NBR 10151;1998 Nov. Projeto -2:135.01-003.

9. United States Environmental Protection Agency. Information on levels of environmental noise requisite to protect public health and welfare with an adequate margin of safety. Washington, DC.: Government Printing Office 1974. (Report No. 550-9-74-004).

10. Otenio MH, Cremer E, Claro EMT. Noise level in a 222 bed hospital in the 18th health region - PR. Rev Bras Otorrinolaringol. 2007; 73(2):245-50. 